\title{
Successive Intercropping of Potato and Mungbean with Sugarcane
}

\author{
Md. Shariful Islam ${ }^{1}$ and M. Obaidul Islam ${ }^{2} *$ \\ ${ }^{1}$ Physiology and Sugar Chemistry Division, Bangladesh Sugar Crop Research Institute, Ishurdi, \\ Pabna, Bangladesh; ${ }^{2}$ Department of Crop Botany, Bangladesh Agricultural University, Mymensingh, \\ Bangladesh \\ *Corresponding author and Email: obaidul7_mo@yahoo.com
}

Received: 20 September 2016

Accepted: 12 December 2016

\begin{abstract}
The experiment was carried out at the Bangladesh Sugarcane Research Institute (BSRI) farm at Ishurdi, Pabna, Bangladesh during2008-2009 and 2009-2010to investigate the growth and yield of main crop sugarcane, and companion crops potato and mungbean as successive intercrops. Row to row spacing (RRS) of sugarcane were $80\left(\mathrm{~S}_{1}\right), 100\left(\mathrm{~S}_{2}\right)$ and $120 \mathrm{~cm}\left(\mathrm{~S}_{3}\right)$ and sugarcane was intercropped with 1,2 and 3 rows of potato as 1 st intercrop and followed by mungbean with same row ratio as $2^{\text {nd }}$ intercrop. Sugarcane and companion crops potato and mungbean were cultivated following the cultivation methods of BSRI and Bangladesh Agricultural Research Institute (BARI), respectively. To provide more light to intercrops bended leaves of sugarcane on both sides of rows were cut at middle and compared with non-cutting of leaves in respect of growth and yield of main crop and intercrops as well. The total dry matter production, cane yield and sugar yield were the highest at $120 \mathrm{~cm}$ RRS of sugarcane (non-leaf cutting $=\mathrm{C}_{0}$ ) intercropped with 3 rows of potato followed by 3 rows of mungbean $\left(\mathrm{S}_{3} \mathrm{C}_{0}\right)$. The number of tiller and millable canes, and leaf area index (LAI) were the highest at $80 \mathrm{~cm}$ RRS of sugarcane $\left(C_{0}\right)$ with one row of potato and one row of mungbean $\left(S_{1} C_{0}\right)$. The effect of light interception on growth and yield of first intercrop (potato) was insignificant whereas it was significant for second intercrop. Yield of mungbean ( $2^{\text {nd }}$ intercrop) and light interception ratio (\%) was the lowest in $\mathrm{S}_{3} \mathrm{C}_{1}$ where sugarcane RRS was $120 \mathrm{~cm}+3 \mathrm{R}$ potato followed by $3 \mathrm{R}$ mungbean with leaf cutting (LC). The results of the experiment indicated that sugarcane transplanted at RRS of $120 \mathrm{~cm}$ with 3 rows of potato followed by 3 rows of mungbean can be grown as intercrops for increased yield of sugarcane as well as for increased cropping intensity and might be recommended for farmers practice in High Ganges River Flood Plain soils under AEZ 11 of Bangladesh.
\end{abstract}

Keywords: Successive intercropping, yield, intensity.

\section{Introduction}

Sugarcane is an important cash-cum-industrial crop of Bangladesh. It has great value to provide sugar for 160 million people of the country. More than half of the global population also depends on sugar produce from sugarcane.
Sugarcane is a long duration crop. It needs about 12-13 months from sett transplanting to harvest and therefore faces more environmental stresses and gives less economic return compare to other cash crops. Stress tolerant and short duration cultivar development, better management practices and adopting high valued intercrops in 
sugarcane are possible steps to get higher economic return from sugarcane cultivation. Intercropping in sugarcane has long been practiced to get interim monetary return. Intercropping helps in diversification of crop production and fulfils the need of farmers (Singh et al., 1986). It is reported that about $80 \%$ farmers are practicing intercropping in sugarcane in Panjab (The Indian express, 2014). Recent report indicates that intercropped soybean not only increases yield but also enhances soil quality through nitrogenise and urease activity in soil which finally enhances nitrogen and phosphorus contents of rhizospheric soil (Li et al., 2013). Sugarcane is usually planted at 80 to $120 \mathrm{~cm}$ row to row spacing (RRS). It needs 3-5 months for full canopy development and therefore, allows selective short duration intercrop. Thus, sugarcane provides ample opportunity for spatial and temporal intercropping to enhance intensification as well as economic return.

However, RRS affects light intensity, intercrop competition and other growth supporting factors which finally affect growth and yield of both sugarcane and companion crop. Higher light intensity and long duration promote the number of tillers in sugarcane while cloudy and short days affect it adversely. Narrow vacant space in between two sugarcane rows affects light interception resulting in higher level of shading on intercrops especially on second intercrop and consequently affects photosynthesis. Wide row spacing is required to receive enough solar radiation for proper photosynthesis, growth and yield of second intercrop (Miah et al., 2002).

Therefore, selection of successive intercrop under RRS of sugarcane is an important factor for sustainable intensification and economic return from sugarcane cultivation. In present study two high valued crops potato and mungbean were cultivated as successive intercrops with sugarcane to estimate growth performance and yield attributes under different spacings. Govinden (1990) claimed intercropping in sugarcane cultivation as a successful system and showed that $22 \%$ more potato was produced over sole crop when cultivated as an intercrop without any loss of sugarcane yield as a main crop. The bulk of the potato in Mauritius is produced on sugarcane lands (Govinden, 1990). However, almost all reports are on single intercrop or pair intercrops in sugarcane. Report on successive intercrop in sugarcane is scarcely available. To fill the gap, present research is planned to estimate row to row spacing of sugarcane transplanting when intercropped with potato and mungbean successively for increased growth and yield.

\section{Materials and Methods}

\subsection{Location and soil properties}

The experiment was conducted at Bangladesh Sugarcane Research Institute (BSRI) farm, Ishurdi, Pabna, Bangladesh in 2008-2009 and repeated in 2009-2010 cropping seasons. The main crop sugarcane (cv. Isd 37) was cultivated with potato (cv. Cardinal) and mungbean (BINA moog 5) as successive intercrop. The site is located at $24^{\circ} 8^{\prime}$ North latitude and $89^{\circ} 04^{\prime}$ East longitude and situated about $15.5 \mathrm{~m}$ above from the mean sea level. The experimental site represents the High Ganges River Flood Plain soils under the Agro ecological zone-11 (AEZ 11). The experiments were laid out in farm field soil having good internal drainage. The land category was medium high land. The soil belongs to 'Sara series' of calcareous soil. The soil was sandy loam in texture having $\mathrm{pH} 7.58$, contained organic carbon $0.88 \%$, total $\mathrm{N}$ (0.05\%), available phosphorus $17.00 \mu \mathrm{g} \mathrm{g} \mathrm{g}^{-1}$, available sulphur $21.0 \mu \mathrm{g} \mathrm{g} \mathrm{g}^{-1}$, exchangeable potassium 0.20 meq $100 \mathrm{~g}^{-1}$, available zinc 0.77 $\mu \mathrm{g} \mathrm{g}^{-1}$ and having cation exchange capacity (CEC) $12.25 \mathrm{meq} 100 \mathrm{~g}^{-1}$ of soil.

\subsection{Treatments and experimental design}

The experiment with two factors (A and B) was laid out in a Randomized Complete Block Design (RCBD) with three replications. The unit plot size was $8 \mathrm{~m} \times 6 \mathrm{~m}$ and separated by $1.0 \mathrm{~m}$ border. 
Factor A (Row to row spacing of sugarcane and number of row of intercrops)

$\mathrm{S}_{1}=$ Sugarcane RRS $80 \mathrm{~cm}+1 \mathrm{R}$ of $1^{\text {st }}$ intercrop followed by $1 \mathrm{R}$ of $2^{\text {nd }}$ intercrop.

$\mathrm{S}_{2}=$ Sugarcane RRS $100 \mathrm{~cm}+2$ rows of $1^{\text {st }}$ intercrop followed by 2 rows of $2^{\text {nd }}$ intercrop.

$\mathrm{S}_{3}=$ Sugarcane RRS $120 \mathrm{~cm}+3$ rows of $1^{\text {st }}$ intercrop followed by 3 rows of $2^{\text {nd }}$ intercrop.

$\mathrm{S}_{4}=$ Sole sugarcane, RRS $100 \mathrm{~cm}$ (farmers practice).

Factor B (Leaf cutting of sugarcane)

$\mathrm{C}_{0}=$ Non leaf cutting (NLC)

$\mathrm{C}_{1}=$ Leaf cutting (LC)

Only bended leaves at bending position of sugarcane were cut (about $20 \%) 3$ times with 21 days interval up to sowing of $2^{\text {nd }}$ intercrop.

\subsection{Land preparation and fertilizer application} The land was ploughed and trenches were made by tractor drawn plough and harrow. Fertilizer ( $\mathrm{kg}$ per hectare) applied in crops is presented in Table 1.

For sugarcane full dose of TSP, Gypsum, $\mathrm{ZnSo}_{4}$ and one-third of MoP were mixed with soil in trench during land preparation. Urea was topdressed at 21, 90 and 150 DAT @ of $1 / 3^{\text {rd }}$ of total dose. Similarly second and $3^{\text {rd }}$ dose $\left(1 / 3^{\text {rd }}\right)$ of MoP was also top dressed at 90 and 150 DAT (FRG, 2005).For potato total amount of TSP, Gypsum and $50 \%$ of urea and $50 \%$ of MoP were mixed with furrow soil as basal dose. The remaining $50 \%$ of urea and $\mathrm{MoP}$ were side dressed in two equal splits at 25 and 45 DAT during first and second earthing-up (Rahman et al. 2005). For mungbean all fertilizers were applied at basal dose at sowing (Rahman et al. 2008).

\subsection{Settlings transplantation and management}

Previously raised 45 days old sugarcane settlings in polybag were transplanted in trenches at 45 $\mathrm{cm}$ plant to plant spacing (PPS) in $2^{\text {nd }}$ week of November for both the years. First intercrop potato tubers (1st intercrop) were also sown on same day and mungbean seeds ( $2^{\text {nd }}$ intercrop) were sown in $1^{\text {st }}$ week of March in ridge just after harvesting of potato. The average seed rate of potato tuber and mungbean were $0.75 \mathrm{t} \mathrm{ha}^{-1}$ and $10 \mathrm{~kg} \mathrm{ha}^{-1}$, respectively as intercrop, while these were $1.5 \mathrm{t} \mathrm{ha}^{-1}$ and $25 \mathrm{~kg} \mathrm{ha}^{-1}$ as sole crop. After transplanting of the settlings irrigation (about $10 \mathrm{~cm}$ ) was given in trenches. Further irrigation was done at 30, 60, 90 and 120 DAT. Dead settling were replaced by healthy settlings within 15 days after transplanting. After each irrigation surface soil of trenches was mulched manually with a khupri. The plots were kept weed free up to 135 DAT. Earthing-up and tying of sugarcane were done after 140 days of plantation. During trench preparation Chlorpyrifos (Regent $3 \mathrm{GR}$ ) was applied in the trenches@33 kg ha ${ }^{-1}$ to control termite and Carbofuran (Furadan5G) was applied as a preventive measure against borers at 90 and 150 days (two times) after planting @ $40 \mathrm{~kg} \mathrm{ha}^{-1}$ for each time (Alam et al., 1990). No disease infestation was observed in sugarcane and intercrop during cultivation.

Table 1. Fertilizer applied in crops (kg per hectare)

\begin{tabular}{lccccc}
\hline \multicolumn{1}{c}{ Crops } & Urea & TSP & MoP & Gypsum & $\mathrm{ZnSO}_{4}$ \\
\hline Sugarcane (main crop) & 325 & 250 & 180 & 190 & 09 \\
Potato (1 $1^{\text {st }}$ intercrop) & 120 & 60 & 100 & 45 & 00 \\
Mungbean (2 $2^{\text {nd }}$ intercrop) & 20 & 40 & 25 & 00 & 00 \\
Sugarcane (sole crop) & 325 & 250 & 180 & 190 & 09 \\
Potato sole (sole crop) & 220 & 120 & 220 & 100 & 08 \\
Mungbean (sole crop) & 30 & 80 & 50 & 50 & 03 \\
\hline
\end{tabular}




\subsection{Data collection and analysis}

For sugarcane, data on plant height, number of tillers, leaf area index, total dry matter, millable cane, cane height, cane diameter and cane yield were collected. Similarly data on $\%$ light interception (measured by a 660/730. Red: Far red measuring system; SKR 110/100 Skys Instruments Ltd. Powys, U.K.) was also collected. Light interception was calculated according to the following formula:

$\%$ light interception $=$

$\left(1.0-\frac{\mathrm{I}}{\mathrm{I}}\right) \times 100$

Where,

(Szeicz et al., 1964).

I = Light intensity received at the ground level

$\mathrm{I}_{0}=$ Light intensity received above the crop canopy

The analysis of variance for different parameters was done and means differences were compared by Duncan's Multiple Range Test (DMRT) using program MSTAT-C (Russel, 1986).

\section{Results and Discussion}

\subsection{Plant height}

Growth parameters of sugarcane varied differently under different RRS with successive intercrops. The highest plant height of sugarcane was $4.25 \mathrm{~m}_{\text {in }} \mathrm{S}_{3}$ (sugarcane RRS $120 \mathrm{~cm}+3 \mathrm{R}$ potato-3 $\mathrm{R}$ mungbean) in 2008-2009 season followed by $S_{2}$ (sugarcane RRS $100 \mathrm{~cm}+2 \mathrm{R}$ potato- $2 \mathrm{R}$ mungbean) and the lowest height was $4.08 \mathrm{~m}$ in $\mathrm{S}_{1}$ (sugarcane RRS $80 \mathrm{~cm}+1 \mathrm{R}$ potato-1 $\mathrm{R}$ mungbean) under successive intercropping of potato-mungbean (Table 2). Similar trend of plant height was observed in 2009-2010 cropping year. The effect of leaf cutting of sugarcane on plant height was insignificant (Table 3). The interaction of RRS and LC or NLC of sugarcane on plant height shows that plant height was the highest $(4.29 \mathrm{~m})$ in $\mathrm{S}_{3} \mathrm{C}_{0}$ (sugarcane RRS $120 \mathrm{~cm}+3 \mathrm{R}$ potato followd by $3 \mathrm{R}$ mungbean with NLC) followed by $\mathrm{S}_{3} \mathrm{C}_{1}$ and the lowest in $\mathrm{S}_{1} \mathrm{C}_{1}$ (sugarcane RRS $80 \mathrm{~cm}+1 \mathrm{R}$ potato-1 $\mathrm{R}$ mungbean with $\mathrm{LC}$ ) in both the years (Table 4).

\subsection{Tiller production and leaf area index (LAI)}

The number of tiller per hill, an important yield contributing character was the highest at the lowest spacing. In $S_{1}$ the number of tiller was $246.00 \times 10^{3} \mathrm{ha}^{-1}$, which decreased to $152.90 \times 10^{3}$ $\mathrm{ha}^{-1}$ in $\mathrm{S}_{3}$ during 2008-2009 (Table 2). Similar trend of number of tiller was observed in 20092010 cropping year. The interaction effects (Table 4) also support that lower spacing enhanced tiller number. Higher LAI was found in lower spacing. Table 4 shows the highest LAI was in $\mathrm{S}_{1} \mathrm{C}_{0}$ followed by $\mathrm{S}_{2}$ and the lowest one was in $\mathrm{S}_{3} \mathrm{C}_{1}$.

Table 2. Effects of RRS on growth of sugarcane with potato-mungbean as successive intercrop

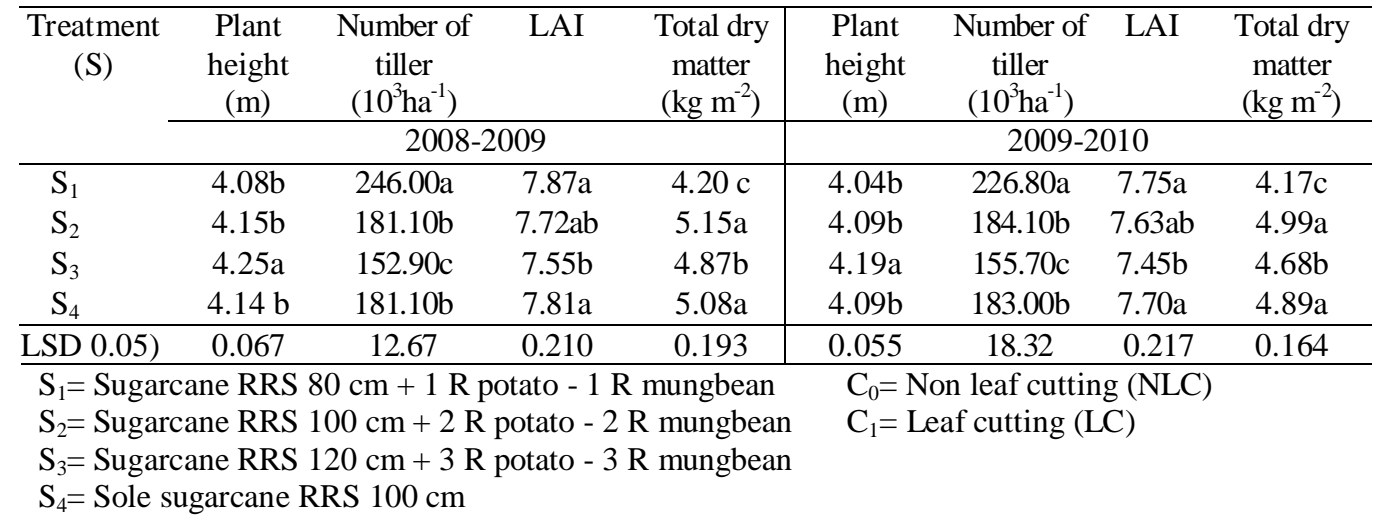

*Figures with similar letter (s) of a column don't differ significantly at 5.0\% probability by DMRT 
Table 3. Effects of LC or NLC on growth of sugarcane with potato-mungbean as successive intercrop

\begin{tabular}{|c|c|c|c|c|c|c|c|c|}
\hline \multirow[t]{2}{*}{ Leaf cutting (C) } & $\begin{array}{c}\text { Plant } \\
\text { height }(\mathrm{m})\end{array}$ & $\begin{array}{c}\text { Number of } \\
\text { tiller } \\
\left(10^{3} \mathrm{ha}^{-1}\right)\end{array}$ & LAI & $\begin{array}{c}\text { Total dry } \\
\text { matter } \\
\left(\mathrm{kg} \mathrm{m}^{-2}\right)\end{array}$ & $\begin{array}{c}\text { Plant height } \\
\text { (m) }\end{array}$ & $\begin{array}{c}\text { Number of } \\
\text { tiller } \\
\left(10^{3} \mathrm{ha}^{-1}\right)\end{array}$ & LAI & $\begin{array}{l}\text { Total dry } \\
\text { matter } \\
\left(\mathrm{kg} \mathrm{m}^{-2}\right)\end{array}$ \\
\hline & \multicolumn{4}{|c|}{ 2008-2009 } & \multicolumn{4}{|c|}{$2009-2010$} \\
\hline No leaf cut $\left(\mathrm{C}_{0}\right)$ & 4.18 & 191.64 & 7.75 & 4.87 & 4.12 & 188.93 & 7.65 & 4.73 \\
\hline Leaf cut $\left(\mathrm{C}_{1}\right)$ & 4.13 & 188.92 & 7.73 & 4.78 & 4.08 & 185.82 & 7.61 & 4.62 \\
\hline LSD (0.05) & NS & NS & $\mathrm{NS}$ & NS & NS & NS & NS & NS \\
\hline
\end{tabular}

Table 4. Interaction effects of RRS and LC or NLC on growth of sugarcane with potato-mungbean as successive intercrop

\begin{tabular}{ccccc|cccc}
\hline $\begin{array}{c}\text { Interaction } \\
(\mathrm{S} \times \mathrm{C})\end{array}$ & $\begin{array}{c}\text { Plant } \\
\text { height } \\
(\mathrm{m})\end{array}$ & $\begin{array}{c}\text { Number of } \\
\text { tiller } \\
\left(10^{3} \mathrm{ha}^{-1}\right)\end{array}$ & \begin{tabular}{c} 
LAI \\
\cline { 2 - 8 }
\end{tabular} & $\begin{array}{c}\text { Total dry } \\
\text { matter }(\mathrm{kg} \\
\left.\mathrm{m}^{-2}\right)\end{array}$ & $\begin{array}{c}\text { Plant } \\
\text { height } \\
(\mathrm{m})\end{array}$ & $\begin{array}{c}\text { Number of } \\
\text { tiller } \\
\left(10^{3} \mathrm{ha}^{-1}\right)\end{array}$ & $\begin{array}{c}\text { LAI } \\
2008-2009\end{array}$ & $\begin{array}{c}\text { Total dry } \\
\text { matter } \\
\left(\mathrm{kg} \mathrm{m}^{-2}\right)\end{array}$ \\
\hline $\mathrm{S}_{1} \mathrm{C}_{0}$ & $4.11 \mathrm{bc}$ & $247.75 \mathrm{a}$ & $7.88 \mathrm{a}$ & $4.28 \mathrm{~d}$ & $4.06 \mathrm{~cd}$ & $228.75 \mathrm{a}$ & $7.76 \mathrm{a}$ & $4.23 \mathrm{~d}$ \\
$\mathrm{~S}_{1} \mathrm{C}_{1}$ & $4.06 \mathrm{c}$ & $244.23 \mathrm{a}$ & $7.86 \mathrm{a}$ & $4.13 \mathrm{~d}$ & $4.02 \mathrm{~d}$ & $224.79 \mathrm{a}$ & $7.74 \mathrm{a}$ & $4.11 \mathrm{~d}$ \\
$\mathrm{~S}_{2} \mathrm{C}_{0}$ & $4.18 \mathrm{~b}$ & $181.74 \mathrm{~b}$ & $7.73 \mathrm{ab}$ & $5.19 \mathrm{a}$ & $4.11 \mathrm{bc}$ & $185.83 \mathrm{~b}$ & $7.65 \mathrm{ab}$ & $5.07 \mathrm{a}$ \\
$\mathrm{S}_{2} \mathrm{C}_{1}$ & $4.13 \mathrm{bc}$ & $180.48 \mathrm{~b}$ & $7.71 \mathrm{ab}$ & $5.12 \mathrm{ab}$ & $4.07 \mathrm{~cd}$ & $82.29 \mathrm{~b}-\mathrm{d}$ & $7.61 \mathrm{ab}$ & $4.91 \mathrm{ab}$ \\
$\mathrm{S}_{3} \mathrm{C}_{0}$ & $4.29 \mathrm{a}$ & $154.49 \mathrm{c}$ & $7.56 \mathrm{~b}$ & $4.91 \mathrm{bc}$ & $4.22 \mathrm{a}$ & $56.87 \mathrm{~cd}$ & $7.49 \mathrm{ab}$ & $4.73 \mathrm{bc}$ \\
$\mathrm{S}_{3} \mathrm{C}_{1}$ & $4.21 \mathrm{ab}$ & $151.36 \mathrm{c}$ & $7.55 \mathrm{~b}$ & $4.84 \mathrm{c}$ & $4.17 \mathrm{ab}$ & $154.58 \mathrm{~d}$ & $7.42 \mathrm{~b}$ & $4.63 \mathrm{c}$ \\
$\mathrm{S}_{4} \mathrm{C}_{0}$ & $4.16 \mathrm{bc}$ & $182.59 \mathrm{~b}$ & $7.84 \mathrm{ab}$ & $5.11 \mathrm{a}-\mathrm{c}$ & $4.12 \mathrm{bc}$ & $84.29 \mathrm{bc}$ & $7.73 \mathrm{a}$ & $4.94 \mathrm{ab}$ \\
$\mathrm{S}_{4} \mathrm{C}_{1}$ & $4.12 \mathrm{bc}$ & $179.63 \mathrm{~b}$ & $7.78 \mathrm{ab}$ & $5.05 \mathrm{a}-\mathrm{c}$ & $4.06 \mathrm{~cd}$ & $81.65 \mathrm{~b}-\mathrm{d}$ & $7.68 \mathrm{ab}$ & $4.85 \mathrm{a}-\mathrm{c}$ \\
\hline $\mathrm{LSD}(0.05)$ & 0.095 & 17.92 & 0.296 & 0.273 & 0.078 & 25.90 & 0.308 & 0.232 \\
\hline
\end{tabular}

\subsection{Total dry matter}

The highest total dry matter production $(5.15 \mathrm{~kg}$ $\mathrm{m}^{-2}$ ) was in $\mathrm{S}_{2}$ and the lowest one was in $\mathrm{S}_{1}$ (Table 2). The effect of leaf cutting and noncutting was ineffective on dry matter production (Table 3). The interaction also shows that the highest total dry matter was produced in $\mathrm{S}_{2} \mathrm{C}_{0}$ and the lowest total dry matter was observed in $\mathrm{S}_{1} \mathrm{C}_{1}$ in both the years (Table 4).

\subsection{Number of millable cane production}

The number of millable cane is an important yield contributing factor. The number of millable cane was the highest $\left(105.90 \times 10^{3} \mathrm{ha}^{-1}\right)$ in $\mathrm{S}_{1}$, followed by $S_{2}\left(97.71 \times 10^{3} \mathrm{ha}^{-1}\right)$ and the lowest one was in $S_{3}\left(91.58 \times 10^{3} \mathrm{ha}^{-1}\right)$. Similar number was also obtained in the next year (Table 5). The effect of leaf cutting of sugarcane had no significant effect on number of millable cane
(Table 6). The interaction effects of RRS and LC or NLC show that the number of millable cane was similar in $\mathrm{S}_{1} \mathrm{C}_{0}$ and $\mathrm{S}_{2} \mathrm{C}_{\mathrm{o}}$, and decreased significantly in $\mathrm{S}_{3} \mathrm{C}_{0}$. The highest number of millable cane was $106.30 \times 10^{3} \mathrm{ha}^{-1}$, produced in $\mathrm{S}_{1} \mathrm{C}_{0}$ and the lowest number $\left(92.32 \times 10^{3} \mathrm{ha}^{-1}\right)$ was in $\mathrm{S}_{3} \mathrm{C}_{1}$ (Table 7).

\subsection{Stalk height and diameter}

Stalk height, an important yield contributing character of sugarcane was the highest $(2.73 \mathrm{~m})$ in $S_{3}$ followed by $S_{2}$ and the lowest one was $(2.50$ $m)$ in $S_{1}$ (Table 5). The interaction effects of RRS and LC or NLC of sugarcane on stalk height shows that the highest stalk height was obtained in $\mathrm{S}_{3} \mathrm{C}_{0}$ in both the years (Table 7). Similar result was obtained for stalk diameter of sugarcane. The highest stalk diameter was observed under higher spacing $\left(\mathrm{S}_{3}\right)$ and the 
lowest $(2.54 \mathrm{~cm})$ was in $S_{1}$. The effect of leaf cutting of sugarcane on stalk diameter was statistically insignificant (Table 6). The interaction effects of RRS and LC or NLC of sugarcane on stalk diameter indicate the highest stalk diameter $(2.56 \mathrm{~cm})$ was found in $\mathrm{S}_{3} \mathrm{C}_{0}$ and the lowest $(2.37 \mathrm{~cm})$ was in $\mathrm{S}_{1} \mathrm{C}_{1}$.

Table 5. Effects of RRS on cane yield component and cane yield of sugarcane with potato-Mungbean as intercrop

\begin{tabular}{|c|c|c|c|c|c|c|c|c|}
\hline $\begin{array}{c}\text { Treatment } \\
\text { (S) }\end{array}$ & $\begin{array}{c}\text { Number of } \\
\text { millable cane } \\
\left(10^{3} \mathrm{ha}^{-1}\right)\end{array}$ & $\begin{array}{l}\text { Stalk } \\
\text { height } \\
(\mathrm{m})\end{array}$ & $\begin{array}{c}\text { Stalk } \\
\text { diameter } \\
(\mathrm{cm})\end{array}$ & $\begin{array}{l}\text { Cane } \\
\text { yield } \\
\left(\mathrm{t} \mathrm{ha}^{-1}\right)\end{array}$ & $\begin{array}{c}\text { Number of } \\
\text { millable cane } \\
\left(10^{3} \mathrm{ha}^{-1}\right)\end{array}$ & $\begin{array}{l}\text { Stalk } \\
\text { height } \\
(\mathrm{m})\end{array}$ & $\begin{array}{c}\text { Stalk } \\
\text { diameter } \\
(\mathrm{cm})\end{array}$ & $\begin{array}{l}\text { Cane } \\
\text { yield } \\
\left(\mathrm{t} \mathrm{ha}^{-1}\right)\end{array}$ \\
\hline & \multicolumn{4}{|c|}{$2008-2009$} & \multicolumn{4}{|c|}{$2009-2010$} \\
\hline $\mathrm{S}_{1}$ & $105.9 \mathrm{a}$ & $2.50 \mathrm{c}$ & $2.39 \mathrm{c}$ & $87.20 \mathrm{~b}$ & $103.90 \mathrm{a}$ & $2.47 \mathrm{c}$ & $2.36 \mathrm{c}$ & $84.01 \mathrm{c}$ \\
\hline $\mathrm{S}_{2}$ & $97.71 b$ & $2.60 \mathrm{~b}$ & $2.46 \mathrm{~b}$ & $96.89 a$ & $94.99 b$ & $2.57 \mathrm{~b}$ & $2.43 b$ & $93.76 \mathrm{a}$ \\
\hline $\mathrm{S}_{3}$ & $91.58 b$ & $2.73 a$ & $2.54 \mathrm{a}$ & $91.06 \mathrm{ab}$ & $89.04 b$ & $2.71 \mathrm{a}$ & $2.52 \mathrm{a}$ & $87.69 b c$ \\
\hline $\mathrm{S}_{4}$ & $97.04 \mathrm{~b}$ & $2.59 \mathrm{~b}$ & $2.45 \mathrm{~b}$ & $95.20 \mathrm{a}$ & $94.73 b$ & $2.55 \mathrm{~b}$ & $2.43 b$ & $91.87 \mathrm{ab}$ \\
\hline$\overline{\mathrm{LSD}(0.05)}$ & 8.087 & 0.055 & 0.039 & 6.303 & 8.767 & 0.039 & 0.039 & 5.272 \\
\hline
\end{tabular}

Table 6. Effects of LC or NLC on cane yield component and cane yield of sugarcane with potatomungbean as intercrop

\begin{tabular}{ccccc|cccc}
\hline Cutting (C) $\begin{array}{c}\text { Number of } \\
\text { millable cane } \\
\left(10^{3} \mathrm{ha}^{-1}\right)\end{array}$ & $\begin{array}{c}\text { Stalk } \\
\text { height } \\
(\mathrm{m})\end{array}$ & $\begin{array}{c}\text { Stalk } \\
\text { diameter } \\
(\mathrm{cm})\end{array}$ & $\begin{array}{c}\text { Cane } \\
\text { yield } \\
\left(\mathrm{t} \mathrm{ha}^{-1}\right)\end{array}$ & $\begin{array}{c}\text { Number of } \\
\text { millable cane } \\
\left(10^{3} \mathrm{ha}^{-1}\right)\end{array}$ & $\begin{array}{c}\text { Stalk } \\
\text { height } \\
(\mathrm{m})\end{array}$ & $\begin{array}{c}\text { Stalk } \\
\text { diameter } \\
(\mathrm{cm})\end{array}$ & $\begin{array}{c}\text { Cane } \\
\text { yield } \\
\left(\mathrm{t} \mathrm{ha}^{-1}\right)\end{array}$ \\
\hline \multicolumn{7}{c}{$2008-2009$} \\
$\mathrm{C}_{0}$ & 98.52 & 2.62 & 2.48 & 93.02 & 96.09 & $2009-2010$ & \\
$\mathrm{C}_{1}$ & 97.58 & 2.58 & 2.44 & 91.96 & 95.26 & 2.55 & 2.42 & 89.78 \\
\hline LSD $(0.05)$ & $\mathrm{NS}$ & $\mathrm{NS}$ & $\mathrm{NS}$ & $\mathrm{NS}$ & $\mathrm{NS}$ & $\mathrm{NS}$ & $\mathrm{NS}$ & $\mathrm{NS}$ \\
\hline
\end{tabular}

Table 7. Interaction effects of RRS and LC or NLC on cane yield component and cane yield of sugarcane with potato-mungbean as intercrop

\begin{tabular}{|c|c|c|c|c|c|c|c|c|}
\hline \multirow[t]{2}{*}{$\begin{array}{l}\text { Interaction } \\
(\mathrm{S} \times \mathrm{C})\end{array}$} & $\begin{array}{c}\text { Number of } \\
\text { millable cane } \\
\left(10^{3} \mathrm{ha}^{-1}\right)\end{array}$ & $\begin{array}{l}\text { Stalk } \\
\text { height } \\
(\mathrm{m})\end{array}$ & $\begin{array}{c}\text { Stalk } \\
\text { diameter } \\
(\mathrm{cm})\end{array}$ & $\begin{array}{c}\text { Cane } \\
\text { yield } \\
\left(\mathrm{t} \mathrm{ha}^{-1}\right)\end{array}$ & $\begin{array}{c}\text { Number of } \\
\text { millable cane } \\
\left(10^{3} \mathrm{ha}^{-1}\right)\end{array}$ & $\begin{array}{c}\text { Stalk } \\
\text { height }(\mathrm{m})\end{array}$ & $\begin{array}{c}\text { Stalk } \\
\text { diameter } \\
(\mathrm{cm})\end{array}$ & $\begin{array}{c}\text { Cane } \\
\text { yield } \\
\left(\mathrm{t} \mathrm{ha}^{-1}\right)\end{array}$ \\
\hline & \multicolumn{4}{|c|}{$2008-2009^{*}$} & \multicolumn{4}{|c|}{ 2009-2010* } \\
\hline$\overline{\mathrm{S}_{1} \mathrm{C}_{0}}$ & $106.30 \mathrm{a}$ & $2.52 \mathrm{~d}$ & $2.42 \mathrm{~cd}$ & $87.93 \mathrm{ab}$ & $104.20 \mathrm{a}$ & 2.49de & $2.38 \mathrm{~cd}$ & $84.05 b$ \\
\hline $\mathrm{S}_{1} \mathrm{C}_{1}$ & $105.50 \mathrm{a}$ & $2.48 \mathrm{~d}$ & $2.37 \mathrm{~d}$ & $86.47 \mathrm{~b}$ & $103.70 \mathrm{a}$ & $2.45 \mathrm{e}$ & $2.35 \mathrm{~d}$ & $83.98 b$ \\
\hline $\mathrm{S}_{2} \mathrm{C}_{0}$ & 98.23ab & $2.63 b$ & $2.48 b c$ & $97.62 \mathrm{a}$ & $95.20 \mathrm{ab}$ & $2.61 \mathrm{~b}$ & $2.45 b$ & $94.39 \mathrm{a}$ \\
\hline $\mathrm{S}_{2} \mathrm{C}_{1}$ & $97.18 \mathrm{ab}$ & $2.57 b c$ & $2.45 \mathrm{c}$ & $96.15 \mathrm{ab}$ & $94.78 \mathrm{ab}$ & $2.54 \mathrm{~cd}$ & $2.41 b c$ & $93.13 \mathrm{a}$ \\
\hline $\mathrm{S}_{3} \mathrm{C}_{0}$ & $92.32 b$ & $2.75 \mathrm{a}$ & $2.56 \mathrm{a}$ & $91.14 \mathrm{ab}$ & $89.16 b$ & $2.72 \mathrm{a}$ & $2.54 \mathrm{a}$ & $88.23 \mathrm{ab}$ \\
\hline $\mathrm{S}_{3} \mathrm{C}_{1}$ & $90.84 b$ & $2.71 \mathrm{a}$ & $2.52 \mathrm{ab}$ & $90.98 \mathrm{ab}$ & $88.93 b$ & $2.69 \mathrm{a}$ & $2.51 \mathrm{a}$ & $87.15 \mathrm{ab}$ \\
\hline $\mathrm{S}_{4} \mathrm{C}_{0}$ & $97.25 \mathrm{ab}$ & $2.61 b$ & $2.46 \mathrm{c}$ & $96.13 \mathrm{ab}$ & $95.82 \mathrm{ab}$ & $2.58 b c$ & $2.44 b$ & $92.45 \mathrm{a}$ \\
\hline $\mathrm{S}_{4} \mathrm{C}_{1}$ & $96.84 \mathrm{ab}$ & $2.58 \mathrm{bc}$ & $2.44 \mathrm{c}$ & $94.27 \mathrm{ab}$ & $93.64 \mathrm{ab}$ & $2.52 \mathrm{~d}$ & $2.42 \mathrm{bc}$ & $91.29 \mathrm{ab}$ \\
\hline$\overline{\mathrm{LSD}(0.05)}$ & 11.44 & 0.078 & 0.055 & 8.914 & 12.40 & 0.055 & 0.055 & 7.456 \\
\hline
\end{tabular}




\subsection{Cane yield}

The highest cane yield was in $\mathrm{S}_{2}$ and the lowest was in $S_{1}$ in both the years (Table 5). The interaction effects of RRS and LC or NLC show that the highest cane yield $\left(97.62 \mathrm{t} \mathrm{ha}^{-1}\right)$ was obtained in $\mathrm{S}_{2} \mathrm{C}_{0}$. Similar cane yield was observed in $\mathrm{S}_{3} \mathrm{C}_{0}$ and the lowest one was $(86.47 \mathrm{t}$ $\mathrm{ha}^{-1}$ ) in $\mathrm{S}_{1} \mathrm{C}_{1}$ (Table 8). Cane yield in sole sugarcane was similar to that in $\mathrm{S}_{3} \mathrm{C}_{0}$ indicated that intercropping did not reduce can yield severely.

\subsection{Yield of first intercrop potato}

Yield of potato (first intercrop) varied significantly with different RRS of sugarcane compared to sole potato. The highest potato tuber yield was $15.28 \mathrm{t} \mathrm{ha}^{-1}$ in $\mathrm{S}_{5}$ (sole potato) and the lowest was $7.79 \mathrm{t} \mathrm{ha}^{-1}$ in $\mathrm{S}_{1} \mathrm{C}_{1}$ (Table 9). The second highest potato yield was in $\mathrm{S}_{3} \mathrm{C}_{1}$ which was significantly lower than that of sole potato. About $28 \%$ yield reduction was observed in potato under intercropping with sugarcane. Light interception (\%) by potato was insignificant in all spacing treatments in both the years. Light interception by potato under successive intercropping was also insignificant (Table 9). At 75 days the light interception was 1.65 at $\mathrm{S}_{3} \mathrm{C}_{0}$ compared to that in $\mathrm{S}_{5}$ (1.29). This indicates that sugarcane leaf did not affect growth and yield of potato.

Table 8. Interaction effects of RRS and LC or NLC on yield of Sugarcane and Potato (1st intercrop), Mungbean (2nd intercrop) as successive intercrop

\begin{tabular}{|c|c|c|c|c|c|c|}
\hline \multirow{3}{*}{ Treatments } & \multirow{2}{*}{$\begin{array}{l}\text { Cane yield } \\
\qquad\left(\mathrm{t} \mathrm{ha}^{-1}\right)\end{array}$} & \multicolumn{2}{|c|}{ Yield of intercrops $\left(\mathrm{t} \mathrm{ha}^{-1}\right)$} & \multirow{2}{*}{$\begin{array}{c}\text { Cane yield } \\
\left(\mathrm{t} \mathrm{ha}^{-1}\right)\end{array}$} & \multicolumn{2}{|c|}{ Yield of intercrops $\left(\mathrm{t} \mathrm{ha}^{-1}\right)$} \\
\hline & & Potato $\left(1^{\text {st }}\right)$ & $\begin{array}{c}\text { Mungbean } \\
\left(2^{\text {nd }}\right)\end{array}$ & & Potato $\left(1^{\text {st }}\right)$ & $\begin{array}{c}\text { Mungbean } \\
\left(2^{\text {nd }}\right)\end{array}$ \\
\hline & \multicolumn{3}{|c|}{$2008-2009 *$} & \multicolumn{3}{|c|}{$2009-2010 *$} \\
\hline $\mathrm{S}_{1} \mathrm{C}_{0}$ & $87.93 \mathrm{ab}$ & $7.84 \mathrm{c}$ & $0.23 \mathrm{e}$ & $84.05 b$ & $6.92 c$ & $0.19 \mathrm{~d}$ \\
\hline $\mathrm{S}_{1} \mathrm{C}_{1}$ & $86.47 \mathrm{~b}$ & $7.79 \mathrm{c}$ & $0.26 \mathrm{e}$ & $83.98 b$ & $6.81 \mathrm{c}$ & $0.23 \mathrm{~d}$ \\
\hline $\mathrm{S}_{2} \mathrm{C}_{0}$ & $97.62 \mathrm{a}$ & $9.67 \mathrm{~b}$ & $0.32 \mathrm{de}$ & $94.39 \mathrm{a}$ & $9.37 \mathrm{~b}$ & $0.24 \mathrm{~d}$ \\
\hline $\mathrm{S}_{2} \mathrm{C}_{1}$ & $96.15 \mathrm{ab}$ & $9.94 b$ & $0.38 \mathrm{~cd}$ & $93.13 \mathrm{a}$ & $9.54 b$ & $0.43 c$ \\
\hline $\mathrm{S}_{3} \mathrm{C}_{0}$ & $91.14 \mathrm{ab}$ & $10.62 b$ & $0.47 \mathrm{c}$ & $88.23 \mathrm{ab}$ & $10.16 b$ & $0.36 \mathrm{c}$ \\
\hline $\mathrm{S}_{3} \mathrm{C}_{1}$ & $90.98 \mathrm{ab}$ & $10.85 b$ & $0.72 b$ & $87.15 \mathrm{ab}$ & $10.25 b$ & $0.74 b$ \\
\hline $\mathrm{S}_{4} \mathrm{C}_{0}$ & $96.13 \mathrm{ab}$ & - & - & $92.45 \mathrm{a}$ & - & - \\
\hline $\mathrm{S}_{4} \mathrm{C}_{1}$ & $94.27 \mathrm{ab}$ & - & - & $91.29 \mathrm{ab}$ & - & - \\
\hline $\mathrm{S}_{5}$ & - & $15.28 \mathrm{a}$ & - & - & $14.75 \mathrm{a}$ & - \\
\hline $\mathrm{S}_{6}$ & - & - & $1.14 \mathrm{a}$ & - & - & $1.16 \mathrm{a}$ \\
\hline $\operatorname{LSD}(0.05)$ & 8.914 & 1.776 & 0.112 & 7.456 & 1.973 & 0.097 \\
\hline
\end{tabular}

*Figures with similar letter (s) of a column don't differ significantly at $5.0 \%$ probability by DMRT

$\mathrm{S}_{1}=$ Sugarcane RRS $80 \mathrm{~cm}+1 \mathrm{R}$ potato $-1 \mathrm{R}$ mungbean

$\mathrm{S}_{2}=$ Sugarcane RRS $100 \mathrm{~cm}+2 \mathrm{R}$ potato $-2 \mathrm{R}$ mungbean

$\mathrm{S}_{3}=$ Sugarcane RRS $120 \mathrm{~cm}+3 \mathrm{R}$ potato $-3 \mathrm{R}$ mungbean

$\mathrm{S}_{4}=$ Sole sugarcane RRS $100 \mathrm{~cm}$

$\mathrm{S}_{5}=$ Sole potato (var. BARI potato 7: Diamant)

$\mathrm{S}_{6}=$ Sole summer mungbean (var. Binamoog-5)
$\mathrm{C}_{0}=$ Non leaf cutting (NLC)

$\mathrm{C}_{1}=$ Leaf cutting (LC) 
Table 9. Effects of interaction between RRS on light interception of potato under successive intercropping of potato-mungbean

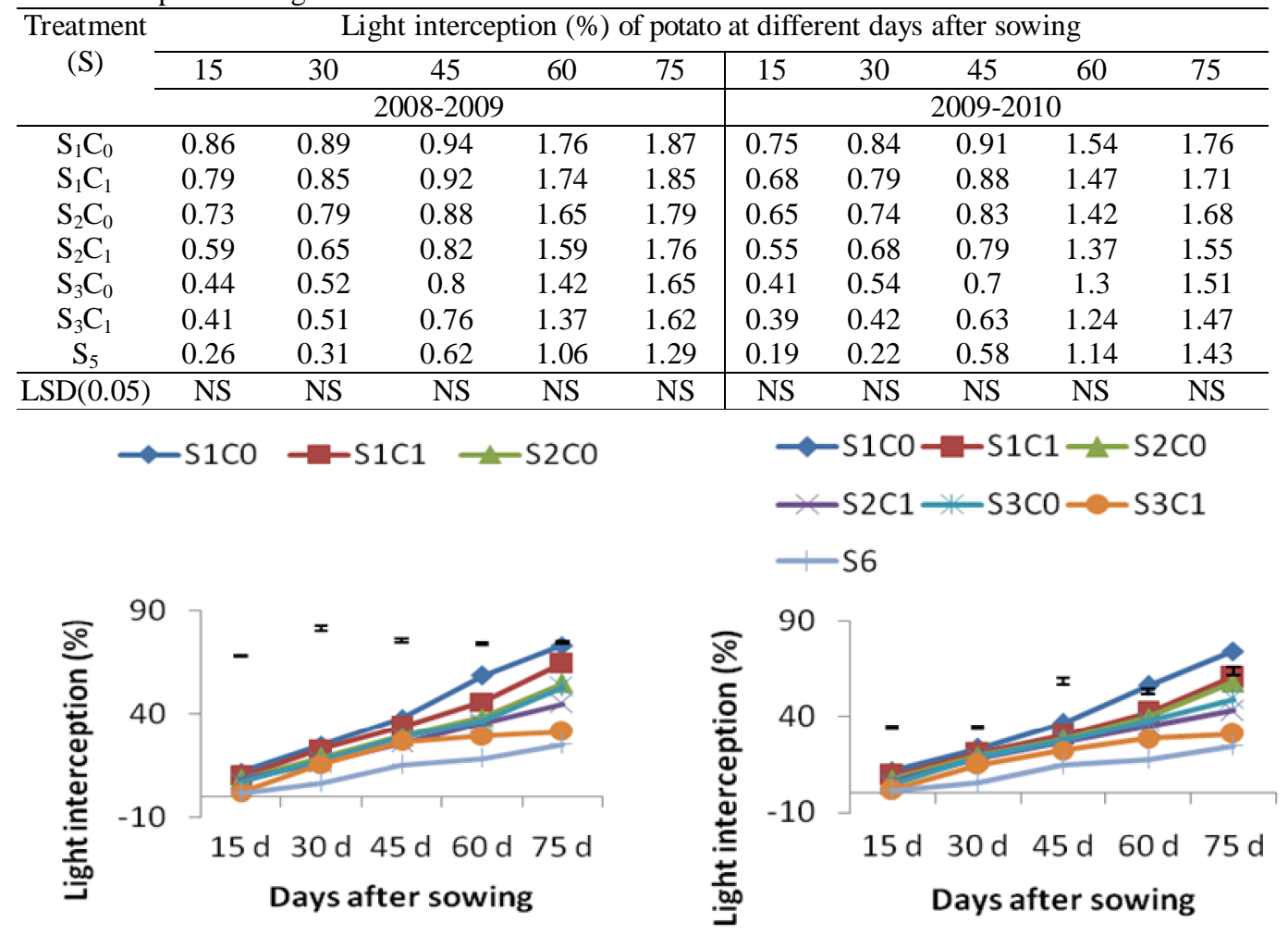

Figure 1. Light interception (\%) of mungbean in 2008-2009. Narrow vertical bars indicate LSD values.

Figure 2. Light interception (\%) of mungbean in 2009-2010. Narrow vertical bars indicate LSD values.

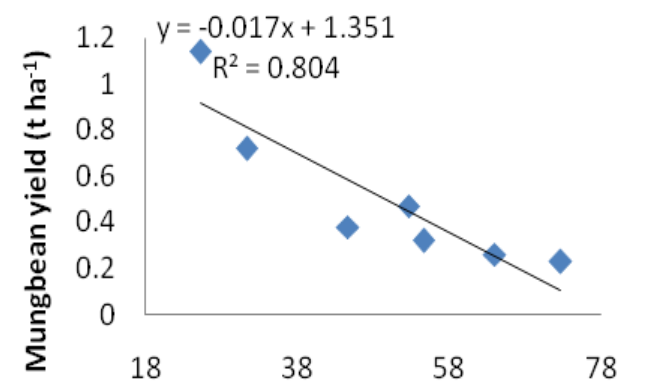

Light interception (\%)

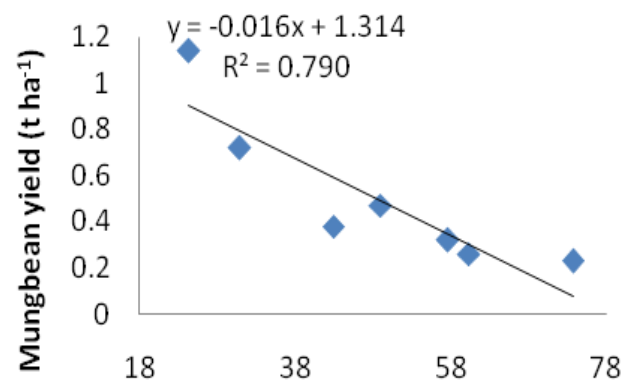

Light interception (\%)

Figure 3. Relationship between light interception (\%) and yield of mungbean at 75 DAS in 2008-2009.

Figure 4. Relationship between light interception (\%) and yield of mungbean at 75 DAS in 2009-2010. 


\subsection{Yield of second intercrop mungbean}

Yield of mungbean as second intercrop with sugarcane varied significantly due to RRS and LC or NLC of main crop of sugarcane. The highest yield of mungbean was in $\mathrm{S}_{3} \mathrm{C}_{1}(0.72 \mathrm{t}$ ha ${ }^{1}$ ) where 3 rows of mungbean was cultivated as second intercrop in $120 \mathrm{~cm}$ row spacing of sugarcane during 2008-2009. Similar result was obtained in 2009-2010. However, the yield of mungbean was significantly lower than that of sole mungbean crop (Table 8). About $36.8 \%$ yield reduction was observed in mungbean due to intercropping in $\mathrm{S}_{3} \mathrm{C}_{1}$ with sugarcane. The lowest yield of mungbean was observed in $\mathrm{S}_{1} \mathrm{C}_{0}$. The highest light interception (\%) was found in $\mathrm{S}_{1} \mathrm{C}_{0}$ and the lowest in $\mathrm{S}_{3} \mathrm{C}_{1}$ in both the years (Figure 2, 3).

A negative correlation between light interception (\%) and grain yield of mungbean at 75 DAS was observed. Mungbean yield and light interception (\%) can be determined by the equation, $\mathrm{Y}=$ $0.017 \mathrm{x}+1.351\left(\mathrm{R}^{2}=0.80\right.$; Figure 3$)$. The equation indicates that mungbean yield can be increased at the rate of $0.80\left(\mathrm{t} \mathrm{ha}^{-1}\right)$ with the decreased in light interception (\%) from 75DAS (Figure 3). Similar relationship was observed in 2009-2010 (Figure 4).

\subsection{Cropping intensification}

Due to intercropping with sugarcane there were 3 crops produced per year without loss of main crop sugarcane. Although yield of both the intercrops decreased under intercropping, the intensity of crop production enhanced to $300 \%$ compared to $100 \%$ at sole sugarcane.

Sugarcane is an important cash cum industrial crop. In early stage it grows slowly and can accommodate a number of short duration crops. Intercropping has been recognized an excellent practice to increase total yield, interim return as well as total high monetary returns, resource utilization, enhance cropping intensification and fulfil the diversified need of farms. There are number of short duration crops like potato, tomato, chilies, onion, garlic, carrot, turnips, cabbage, knoll kohl, lettuce, coriander, peas, lady's finger, linseed, fennel, arson, ray, sunflower, lentil and wheat which can be intercropped with sugarcane. Farmers have also long been practicing intercrop with sugarcane for interim income. However, most of growers practice single crop intercropping in sugarcane. Major intercrop combinations in sugarcane identified are: sugarcane + potato, sugarcane + onion, sugarcane + wheat, sugarcane + coriander, sugarcane + mustard, sugarcane + tomato and sugarcane + cabbage, sugarcane + garlic, sugarcane + sunflower etc. From intercropping practices, pest management benefit has been realized due to increased crop diversity, and intercropping reduced smut disease of sugarcane by interrupting the smut spores (Dawn, 2006). Planting of intercropping should be done in inter-row spaces and plant to row spaces should be critically maintained to avoid undue competition. Very little research effort has been made pertaining to input use, seasonal pattern of production and other practices followed by farmers. The present result documented that growth and yield of sugarcane and two successive intercrops was satisfactory at $120 \mathrm{~cm}$ RRS of sugarcane. Ultimately it will enhance cropping intensification and interim return as well as total income of farmers.

The economics of sugarcane is questioned when farmers earn more profit from other crops. If farmers follow various intercropping practices to increase interim income from sugarcane cultivation it will enhance total farm income from sugarcane cultivation. The present experiment strongly supported that sugarcane row to row spacing $120 \mathrm{~cm}$ under leaf cutting was the best for the highest growth and yield of sugarcane with 3 rows of potato followed by 3 rows of mungbean. Similar double and successive intercropping in sugarcane was supported by Hossain et al. (2003). Present result fully agreed to that report where potato was first intercrop and sesame was the second intercrop in sugarcane. Yield reduction of first intercrop was due to space limitation but in second intercrop due to light as well as space limitation under $\mathrm{S}_{3} \mathrm{C}_{1}$. This result might support increased 
cropping intensity and income generation from sugarcane cultivation in AEZ 11 of Bangladesh.

\section{Conclusions}

From the research result it may be concluded that sugarcane is to be cultivated at row to row spacing of $120 \mathrm{~cm}$ under leaf cutting with 3 rows of potato followed by 3 rows of mungbean for higher growth and yield of sugarcane with higher cropping intensity and interim income generation.

\section{References}

Alam, M. A., Biswas, M. M. and Ali, Y. 1990. Akher khatikar pokamakar o protikar (in Bangla). Sugarcane Research and Training Institute, Ishurdi, Pabna, Bangladesh.

Dawn news, 2006. Returns on inter-cropping in sugarcane cultivation. September 18. http://www.dawn.com/news/210797/ returns-on-inter-cropping-in-sugarcanecultivation.

FRG (Fertilizer Recommendation Guide). 2005. Bangladesh Agricultural Research Council, Farmgate, Dhaka.

Hossain, G. M. A., Bokhtiar, S. M., Paul, S. K. and Anam, M. R. 2003.Intercropping of sugarcane with Onion and Potato Followed by Sesame in Paired Row System. Journal of Agronomy, 2: 85-91.

Govinden, N. 1990. Intercropping of sugar-cane with potato in Mauritius: A successful cropping system. Field Crops Research. 25(1-2):99-110

Miah, M. A. S., Rahman, A. B. M. M., Hossain, M. A., Chowdhury, M. K. A., Alam, M. R. and Ali, S. 2002. Paired row planting technique and sequential intercropping in sugarcane. Pakistan Sugar Journal. 17: 26.

Rahman, M. K., Paul S. K. and Chowdhury, A.T.M. S.U. 2005. Improved cultivation technology of sugarcane and intercrops. Bangladesh Sugarcane Research Institute. Ishurdi, Pabna, Bangladesh. 108: 1-80.

Rahman, M. S., Satter, M. A., Huleder, A. R., Begum, N., Begum, S., Azam, M. A., Miah, M. N. H., Pasa, M. N. U. and Raider, M. R. 2008. Unnoto Krishi Projukti Poreceite (Modern Introducing on Agro-technology) by BINA developed in Bangla. Bangladesh Institute of Nuclear Agriculture. Mymensingh -2200, Bangladesh. 54-61 pp.

Russel, D. F. 1986. MSTAT-C.MSTAT Director Crop and Soil Science. Department of Michigan State University, USA.

Singh, V., Kothari, S. K. and Tripathi, H. N. 1986. Studies on intercropping in sugarcane in central Uttar Pradesh. Indian Sugar Journal. 35: 559-562.

Szeicz, J., Monteith, L., and Santos, M. J. D. 1964. Tube solarimeter to measure radiation among plants. Journal of Applied Ecololy. 1: 169-174.

The Indian Express. (2014). To promote sugarcane, the additional crop between rows. January, 24. http://indianexpress.com/article/india/indi a-others/to-promote-sugarcane-theadditional-crop-between-rows/

Vanis, S. R. , Ahmad, R., Jabbar, A., Mohmood, T. and Ahmad, A. 2000. Biological trails of autumn sugarcane as influenced by special arrangement and publication methods. Pakistan Sugar Journal. 15(5): 15-19.

Li, X., Mu, Y., Cheng, Y., .2013. Effects of intercropping sugarcane and soybean on growth, rhizosphere soil microbes, nitrogen and phosphorus availability. Acta Physiologiae Plantarum. 35:1113. doi: 10.1007/s11738-012-1148-y 